\title{
EVALUASI KETAHANAN GEMPA PADA STRUKTUR GEDUNG X DI JAKARTA BERDASARKAN SNI 03-1726-2012
}

\author{
(Evaluation Earthquake Resistance X Building Structure in Jakarta
} based on SNI 03-1726-2012)

\author{
Sayed Ahmad Fauzan ${ }^{1}$, Erizal ${ }^{2}$, Asep Sapei ${ }^{2}$ \\ 1,2,3 Departemen Teknik Sipil dan Lingkungan, Fakultas Teknologi Pertanian, Institut Pertanian Bogor. \\ Jl. Raya Dramaga, Kampus IPB Dramaga, PO BOX 220, Bogor, Jawa Barat Indonesia \\ Penulis korespondensi : Sayed Ahmad Fauzan. Email: sayed8376@gmail.com
}

\begin{abstract}
Earthquake risk in Jakarta is the intermediate category in Indonesia based on the 2010 seismic hazard map published by the Ministry of Public Works, Republic of Indonesia. It was important to know the condition of the building that would be affected by earthquake load and to prevent collapse of the building structures that could cause loss of live people in the building and the collisions between buildings. The purpose of this research was to know the ultimate performance limit of the existing X building in Jakarta. Evaluation of these building was based on guidelines SNI 03-1726-2012, SNI 03-2847-2013 and PPPURG 1987. The structure model of $X$ building was designed and analyzed using ETABS Version 9.7.2. The result showed value of story drift was affected by dynamic response spectrum load, the maximum drift in $x$-direction is $68.60 \mathrm{~mm}$ and $y$-direction is $101.2 \mathrm{~mm}$. The X building was declared unsafe in performance condition of the ultimate limits.
\end{abstract}

Keywords : building, earthquake, respon spectrum analysis, story drift.

\section{PENDAHULUAN}

Jakarta merupakan wilayah yang memiliki resiko gempa tingkat menengah berdasarkan peta zonasi gempa tahun 2010 yang dipublikasikan oleh Kementrian Pekerjaan Umum Republik Indonesia. Upaya mitigasi kegagalan struktur gedung di wilayah Jakarta akibat gempa sangat perlu dilakukan guna mengetahui kondisi kinerja struktur gedung tersebut agar tetap dapat memikul beban yang diterimanya, terutama beban gempa berdasarkan peraturan pembebanan yang terbaru. Menurut Budiono dan Supriatna (2011), dalam perencanaan struktur bangunan tahan gempa diperlukan standar dan peraturan-peraturan perencanaan bangunan untuk menjamin kesalamatan penghuni serta menghindari dan meminimalisasi kerusakan struktur dan korban jiwa terhadap gempa bumi yang sering terjadi. Kegagalan struktur bangunan bisa disebabkan antara lain oleh kesalahan perhitungan dalam perencanaan, tidak sesuainya perencanaan dengan implementasi pelaksanaan pekerjaan di lapangan, perubahan fungsi bangunan, bencana alam seperti gempa bumi kuat dan lainnya. Menurut Christiawan et.al (2008), evaluasi kinerja struktur gedung dapat dilakukan dengan cara menganalisis kinerja batas ultimum dan kinerja batas layan berdasarkan SNI 03-1726-2002.

Menurut BSN (2012), SNI 03-17262012 yang berisi tentang pedoman tata cara perencanaan ketahanan gempa untuk struktur bangunan gedung dan non-gedung yang merupakan revisi dari SNI 03-17262002. Pedoman SNI 03-1726-2012 telah menggunakan peta riwayat gempa terbaru sejak 2010 sehingga bangunan gedung yang dibangun sebelum tahun 2010 perlu dilakukan evaluasi struktur untuk 
mengetahui keamanan struktur menurut standar yang baru. Perbedaan pedoman perencanaan gedung untuk ketahanan gempa SNI 03-1726-2002 dan SNI 03-

1726-2012, yaitu desain percepatan spektral gempa SNI 03-1726-2012 di beberapa wilayah Indonesia mengalami kenaikan pada jenis kelas situs tanah sedang dan tanah keras dan penurunan pada jenis kelas situs tanah lunak (Arfiandi dan Satyarno 2013).

Gedung $\mathrm{X}$ yang menjadi objek penelitian dalam studi ini belum memiliki Sertifikat Laik Fungsi Bangunan Gedung sesuai Peraturan Menteri Pekerjaan Umum Nomor 25/PRT/M/2007. Bangunan gedung yang memiliki jumlah lantai lebih dari 2 dapat mengajukan sertifikasi kelaikan fungsi bangunan gedung setiap 5 tahun sekali, hal tersebut tertulis dalam Peraturan Menteri Pekerjaan Umum Nomor 25/PRT/M/2007 (DPU 2007).

Gedung yang dibangun sebelum tahun 2012 tersebut tentu telah direncanakan dengan matang oleh konsultan perencana. Namun demikian, dalam hal pengawasan dan pengelolaannya, gedung tersebutharus tetap dievaluasi oleh tim ahli bangunan gedung sepanjang gedung tersebut berdiri agar diketahui kondisi kinerja struktur gedung tersebut untuk masa sekarang. Hal inilah yang mendasari perlu dilakukannya penelitian tentang evaluasi kinerja struktur gedung-gedung bertingkat tinggi di Jakarta yang dibangun sebelum tahun 2012. Tujuan dari penelitian ini yaitu, untuk mengetahui kinerja batas ultimum struktur Gedung $X$ di Jakarta berdasarkan pembebanan gempa SNI 03-1726-2012. Penting untuk diketahui bahwa simpangan yang akan terjadi akibat dari pengaruh beban gempa dapat menyebabkan kemungkinan terjadinya keruntuhan struktur dan benturan antar gedung sehingga menimbulkan korban jiwa.

Pemodelan struktur gedung dapat dianalisis menggunakan program Extended Three Dimensional Analysis of Building
System (ETABS) versi 9.7.2. Program tersebut menghasilkan analisis struktur berupa gaya-gaya dalam yang dapat digunakan untuk mengevaluasi kinerja struktur gedung akibat pembebanan gravitasi ataupun gempa. Metode pembebanan gempa untuk gedung tinggi atau gedung tidak beraturan dapat dilakukan dengan analisis dinamik (Priyono et.al 2014). Metode pembebanan gempa juga dapat dilakukan dengan analisis beban dorong atau pushover analysis (Yalciner et.al 2015).

\section{METODOLOGI}

Data yang menjadi pendukung dalam penelitian ini adalah gambar as built drawing, gambar arsitektur dan referensi tentang peta kelas situs jenis tanah. Pengecekan kondisi kini gedung dilakukan melalui pengamatan visual dan Hammer Test. Hammer Test merupakan suatu pengujian tanpa merusak (non-destructive) untuk mengetahui kualitas mutu dari suatu struktur beton (Snell 2012). Pengujian dilakukan dengan mengambil 5 sampel titik uji pada objek elemen struktur, kemudian dihitung nilai rata-rata yang otomatis terlihat pada alat Hammer Test. Gambar as built drawing menunjukkan bahwa mutu beton yang digunakan pada saat pelaksanaan merupakan K-350 atau setara dengan 29,05 Mpa. Pada saat dilakukan uji mutu beton pada Gedung X, didapatkan rata-rata nilai mutu beton masih sesuai dengan gambar as built drawing. Kegiatan pengecekan kondisi mutu beton diperlukan untuk membuktikan mutubeton pada gambar as built drawing, apakah mutu beton telah sesuai dengan implementasi pelaksanaan di lapangan. Hal ini sangat penting karena nilai mutu kuat tekan beton (f'c) akan dimasukkan kedalam pemodelan struktur gedung.

Pemodelan struktur gedung dianalisis oleh Program ETABS. Pemberian analisis beban gempa dilakukan 
menggunakan grafik respon spektrum dari prosedur analisis spektrum respons ragam. Respons spektrum merupakan grafik hubungan nilai puncak respons struktur percepatan akibat eksitasi gempa sebagai fungsi dari periode alamiah sistem struktur.

Spektrum gempa dibuat berdasarkan peta gempa Indonesia 2010. Pembuatan spektrum gempa disesuaikan dengan letak geografis dan kategori kelas jenis situs tanah bangunan. Lokasi yang menjadi objek penelitian ini adalah wilayah DKI Jakarta. Berdasarkan peta klasifikasi tanah DKI Jakarta menurut Asrurifak et al. (2013) pada lokasi objek penelitian Gedung X termasuk dalam kategori jenis kelas situs tanah lunak (SE). Berdasarkan peta zonasi gempa SNI 03-1726-2012, nilai percepatan batuan dasar 1 detik $\left(S_{1}\right)$ untuk daerah Jakarta berkisar antara 0,25$0,3 \mathrm{~g}$ dan nilai percepatan batuan dasar 0,2 detik (Ss) untuk daerah Jakarta berkisar antara $0,6-0,7 \mathrm{~g}$.

Kombinasi pembebanan dimasukkan kedalam pemodelan berdasarkan Pedoman Peraturan Pembebanan untuk Rumah dan Gedung (PPPURG) 1987 dan pembebanan gempa diberikan secara dinamik respons spektrum berdasarkan SNI 03-1726-2012. Berikut ini detail kombinasi pembebanan untuk beban mati nominal, beban hidup nominal dan beban gempa nominal yang dimasukkan pada pemodelan ETABS berdasarkan SNI 03-1726-2012 Pasal 7.4.2.

1) $1,4 \mathrm{DL}$

2) $1,2 \mathrm{DL}+1,6 \mathrm{LL}+0,5 \mathrm{Lr}$

3) $1,2 \mathrm{DL}+1,6 \mathrm{Lr}+1 \mathrm{LL}$

4) $1,2 \mathrm{DL}+1 \mathrm{WL}+1 \mathrm{LL}+0,5 \mathrm{Lr}$

5) $1,2 \mathrm{DL}+1,1 \mathrm{LL} \pm 0,3\left(\rho \mathrm{QE}+0,2 \mathrm{~S}_{\mathrm{DS}} \mathrm{DL}\right)$ $\pm 1\left(\rho \mathrm{QE}+0,2 \mathrm{~S}_{\mathrm{DS}} . \mathrm{DL}\right)$

6) $1,2 . \mathrm{DL}+1,1 \mathrm{LL} \pm 1\left(\rho \mathrm{QE}+0,2 \mathrm{~S}_{\mathrm{DS}} \mathrm{DL}\right)$ $\pm 0,3\left(\rho \mathrm{QE}+0,2 \mathrm{~S}_{\mathrm{DS}} . \mathrm{DL}\right)$.

7) $0,9 \mathrm{DL}+1 \mathrm{WL}$

8) $0,9 . \mathrm{DL} \pm 0,3\left(\rho \mathrm{QE}-0,2 \mathrm{~S}_{\mathrm{DS}} . \mathrm{DL}\right) \pm$ $1\left(\rho \mathrm{QE}-0,2 \mathrm{~S}_{\mathrm{DS}}\right.$.DL).

9) $0,9 \mathrm{DL} \pm 1\left(\rho \mathrm{QE}-0,2 \cdot \mathrm{S}_{\mathrm{DS}} \mathrm{DL}\right) \pm$ $0,3\left(\rho \mathrm{QE}-0,2 \mathrm{~S}_{\mathrm{DS}}\right.$.DL).
Analisis pembebanan yang diperhitungkan pada pemodelan struktur ini, diantaranya pembebanan statik dan dinamik berdasarkan PPPURG 1989. Sedangkan, untuk pembebanan dinamik gempa berdasarkan SNI 03-1726-2012. Menurut DPU (1987), nilai besaran pemberian beban pada gedung, antara lain: beban hidup lantai untuk fungsi perkantoran sebesar $250 \mathrm{~kg} / \mathrm{m}^{2}$, bebanmati dinding setengah bata sebesar $250 \mathrm{~kg} / \mathrm{m}^{2}$, beban mati untuk lantai parkir bawah sebesar $800 \mathrm{~kg} / \mathrm{m}^{2}$ dan beban mati lantai parkir diatasnya sebesar $400 \mathrm{~kg} / \mathrm{m}^{2}$. Nilai faktor reduksi tulangan berdasarkan pada SNI 03-2847-2013 antara lain: faktor reduksi untuk lentur tulangan tarik sebesar 0,9 ; faktor reduksi untuk lentur tulangan tekan spiral sebesar 0,75 dan tulangan tekan jenis lainnya sebesar 0,65 ; faktor reduksi untuk geser sebesar 0,75 dan faktor reduksi untuk torsi sebesar 0,75 (BSN 2013).

Pembebanan dengan analisis
spektrum respons ragam harus menyertakan jumah ragam yang cukup untuk mendapatkan partisipasi massa ragam terkombinasi sebesar paling sedikit 90\% dari massa aktual dalam masingmasing arah ortogonal dari respons yang ditinjau oleh model, hal ini sesuai dengan ketentuan SNI 03-1726-2012 pasal 7.9.1.

Pemberian beban gempa dalam studi ini harus memenuhi persyaratan SNI 031726-2012 pasal 7.9.4.1, apabila nilai gaya geser dasar seismik analisis spektrum respons ragam $(\mathrm{Vt})$ lebih kecil $85 \%$ dari gaya geser dasar seismik respons ragam petama melalui analisis statik ekivalen lateral $\left(\mathrm{V}_{1}\right)$, maka nilai $\mathrm{Vt}$ harus dikalikan $\left(0,85 \mathrm{~V}_{1}\right) / \mathrm{Vt}$ (faktor skala gaya).

Pembebanan gaya geser dasar seismik spektrum respons ragam $(\mathrm{Vt})$ harus memperhitungkan faktor redudansi $(\rho)$ yang disyaratkan SNI 03-1726-2012 pasal 7.3.4.2. Pasal tersebut menjelaskan bahwa apabila nilai $\mathrm{Vt}$ pada masing-masing tingkat belum memenuhi 35\% dari Vt arah- 
$\mathrm{x}$ dan $\mathrm{y}$, maka nilai $\mathrm{Vt}$ tersebut harus dikalikan dengan faktor redudansi $(\rho)$ sebesar 1,3. Jika tiap lantai telah memenuhi

$35 \%$ dari Vt, maka diizinkan nilai $\rho=1$. Pada program ETABS, nilai faktor redudansi dapat diberikan dengan cara mengalikan nilai faktor redudansi tersebut kedalam faktor skala untuk U1 pada arah-X dan U2 pada arah-y.

Hasil dari analisis struktur akan menghasilkan gaya-gaya dalam, antara lain: gaya momen, geser, torsi dan axial. Program ETABS juga dapat mengeluarkan data output berupa base shear dan displacement atau total drift. Nilai total drift disebut juga dengan nilai perpindahan elastis di lantai tingkat $\mathrm{x}(\delta \mathrm{ex})$. Nilai perpindahan elastis antar lantai diperoleh dari hasil selisih nilai $\delta$ ex lantai tingkat atas dikurangi $\delta$ ex lantai tingkat bawah. Berdasarkan SNI 03-1726-2012, nilai perpindahan elastis antar lantai (storydrift) harus dihitung dengan faktor perbesaran atau amplifikasi defleksi dan faktor keutamaan gempa. Nilai perpindahan atau simpangan antar lantai tingkat (story drift) yang diperbesar, ditentukan melalui persamaan (1) (BSN 2012),
$\delta_{\mathrm{x}}=\frac{C_{d} \cdot \delta_{e x}}{I e}$

\section{Keterangan:}

$\mathrm{Cd}=$ Faktor amplifikasi defleksi (Tabel 9 pada SNI 03-1726-2012 pasal 7.2.2 )

$\delta_{\mathrm{ex}}=$ Perpindahan elastis antar tingkat $\mathrm{x}$ Ie $=$ Faktor keutamaan gempa (SNI 031726-2012 pasal 4.1.2)

Hasil dari penelitian ini akan diperoleh kinerja batas ultimum dari nilai story drift. Struktur gedung dianggap mampu memikul beban gempa apabila nilai story drift tidak melampaui nilai story drift izin $(\Delta \mathrm{a})$ yang dihitung berdasarkan SNI 03-1726-2012 pasal 7.12.1.

Kinerja batas ultimum ditentukan oleh nilai simpangan antar tingkat maksimum struktur akibat pengaruh gempa rencana dalam kondisi strutur gedung diambang keruntuhan, hal ini dimaksudkan untuk mengetahui kemungkinan terjadinya keruntuhan struktur gedung yang dapat menimbulkan korban jiwa dan benturan antar gedung. Sehingga stuktur gedung harus direncanakan dengan nilai simpangan antar lantai tidak melebihi nilai batas simpangan yang diizinkan.

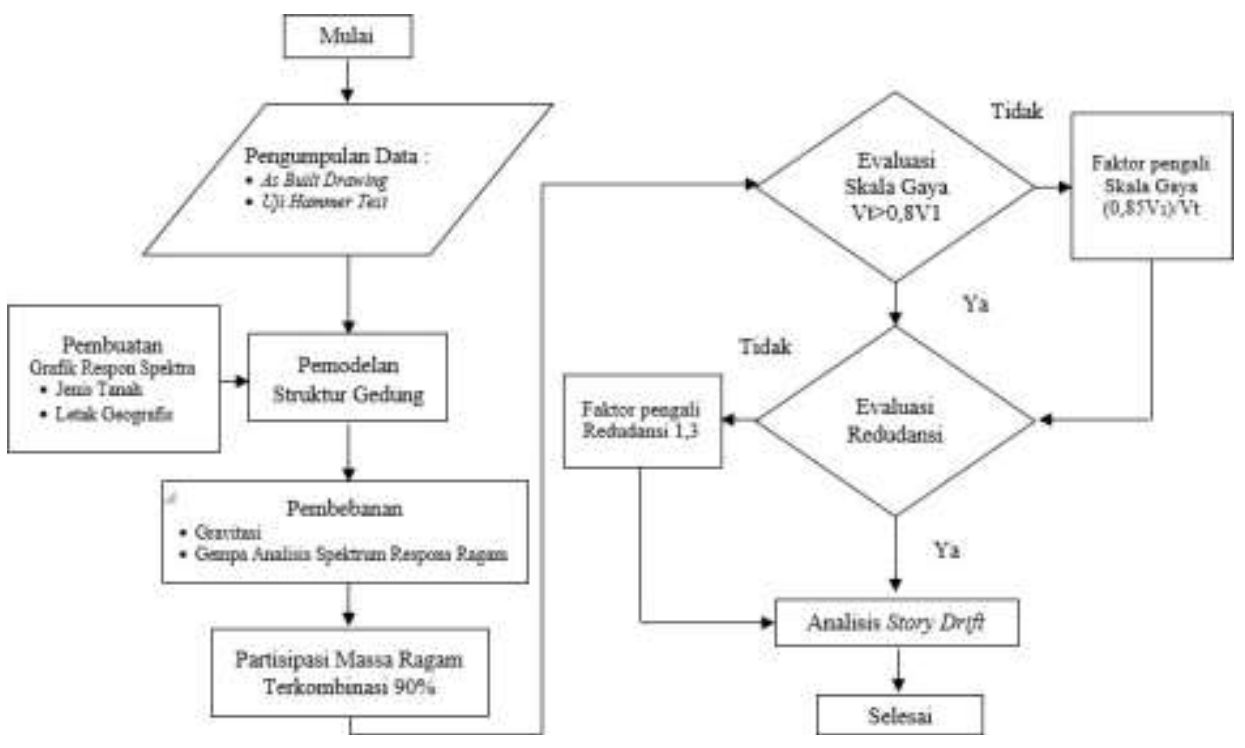

Gambar 1 Diagram alir metode penelitian 


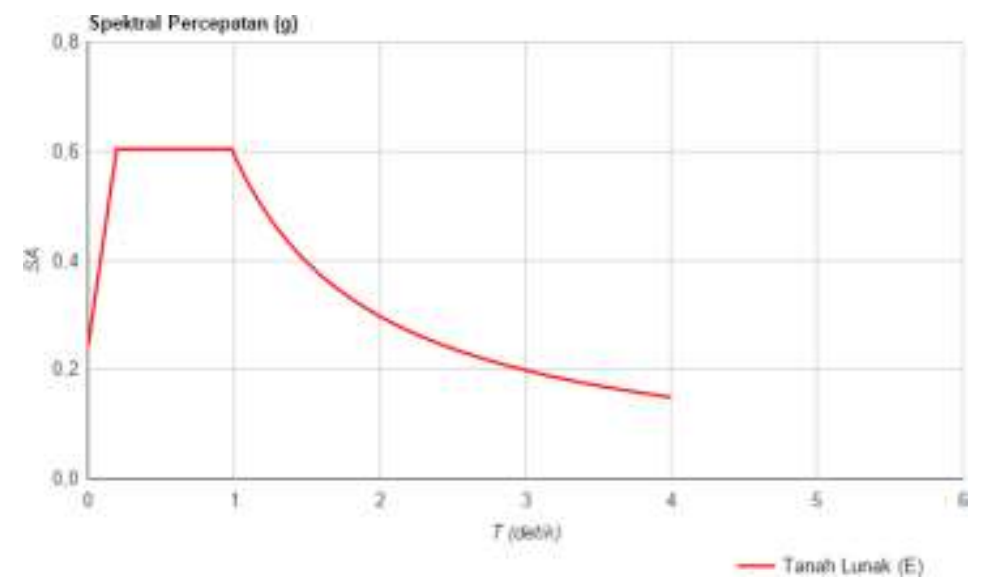

Gambar 2 Grafik desain respons spektra gedung pada lokasi objek penelitian

Prosedur penelitian ditampilkan kategori wilayah klasifikasi jenis tanah dalam diagram alir metode penelitian lunak. dibawah ini (Gambar 1).

\section{HASIL DAN PEMBAHASAN}

\section{Desain Percepatan Respon Spektral}

Nilai desain percepatan respons spektra diperoleh dari hasil analisa website Aplikasi Desain Spektra Pusat Penelitian dan Pengembangan Pemukiman (PUSKIM), Kementrian Pekerjaan Umum. Secara khusus, objek penelitian pada studi ini terletak di Jakarta Timur. Menurut peta klasifikasi tanah DKI Jakarta yang dikeluarkan oleh Asrurifak et al. (2013), bahwa lokasi gedung $\mathrm{X}$ yang terletak pada daerah Jakarta Timur termasuk dalam
Hasil analisis dari website PUSKIM diperoleh tabel dan grafik respon spektra. Data nilai desain percepatan respons spektra yang diperoleh antara lain: nilai percepatan batuan dasar 0,2 detik $(\mathrm{Ss})=$ 0,667 g; percepatan batuan dasar 1 detik $\left(\mathrm{S}_{1}\right)=0,293 \mathrm{~g} ;$ spektrum respons percepatan pada perioda pendek $\left(\mathrm{S}_{\mathrm{MS}}\right)=$ 0,991 g; spektrum respons percepatan pada perioda 1 detik $\left(S_{M 1}\right)=0,929 \mathrm{~g}$, percepatan spektral desain untuk perioda pendek $\left(\mathrm{S}_{\mathrm{DS}}\right)$ $=0,607 \mathrm{~g}$; percepatan spektral desain untuk perioda 1 detik $\left(\mathrm{S}_{\mathrm{D} 1}\right)=0,553 \mathrm{~g}$; Periode $(\mathrm{Ts})=0,901 \mathrm{~s}$ dan Periode $(\mathrm{To})=0,182 \mathrm{~s}$ (Gambar 2).

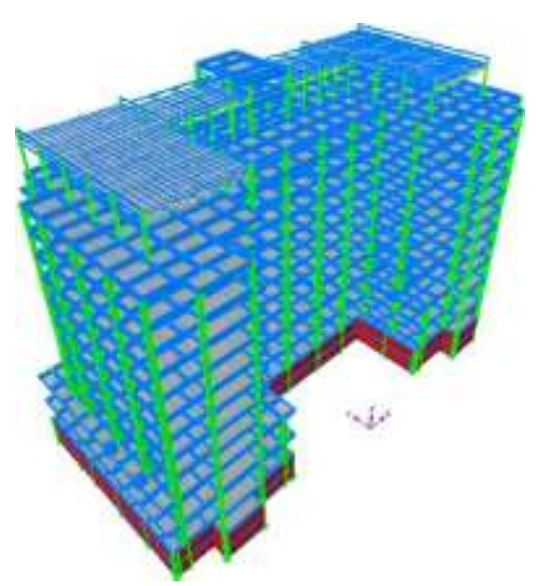

Gambar 3 Pemodelan 3D struktur gedung pada program ETABS 
Tabel 1 Deskripsi gedung

\begin{tabular}{ll}
\hline Deskripsi Gedung & Keterangan \\
\hline Sistem struktur & SRPMM Beton \\
Kategori resiko (SNI 03-1726-2012, pasal 4.1.2) & II \\
Elevasi tertinggi dan elevasi terendah & $+56,50 \mathrm{~m}$ dan $-6,40 \mathrm{~m}$ \\
Jumlah lantai dan basement & 12 lantai dan 2 basement \\
Tinggi lantai tipikal dan lantai basement & $4,00 \mathrm{~m}$ dan 3,20 m \\
Mutu tulangan ulir diameter $(\mathrm{D})>12 \mathrm{~mm}$ & BJTD 390 MPa \\
Mutu tulangan polos diameter $(\varnothing)<12 \mathrm{~mm}$ & BJTP 240 MPa \\
Mutu kuat tekan beton & K-350 = 29,05 Mpa \\
Luas total bangunan & $4.735,71 \mathrm{~m} 2$ \\
Penghubung vertikal & Lift dan Tangga \\
\hline
\end{tabular}

Berdasarkan SNI 03-1726-2012 pasal 4.1.2, tentang kategori risiko struktur bangunan, maka gedung objek penelitian termasuk jenis pemanfaatan sebagai gedung perkantoran dengan kategori resiko II dan faktor keutamaan (Ie) $=1,00$. Berdasarkan SNI 03-1726-2012 pasal 6.5, tentang penentuan Kategori Desain Seismik (KDS), untuk nilai $\mathrm{SD}_{\mathrm{S}}=0,607 \mathrm{~g}$, $\mathrm{SD}_{1}=0,553 \mathrm{~g}$ dan kategori risiko II (perkantoran), diperoleh jenis KDS pada gedung $\mathrm{X}$ tergolong pada tipe $\mathrm{D}$.

\section{Pemodelan Struktur Gedung}

Pemodelan Gedung X dianalisis oleh software program analisis struktur ETABS. Struktur Gedung $X$ secara umum menggunakan material struktur beton, namun untuk struktur atap, balok dan kolom pada lantai 12 dibangun menggunakan material struktur atap baja (Gambar 3). Berikut data deskripsi gedung yang diambil dari data as built drawing tahun 2003-2007 (Tabel 1). Berdasarkan SNI 03-1726-2012 pasal 4.1.2, tentang kategori risiko struktur bangunan, maka gedung objek penelitian termasuk jenis pemanfaatan sebagai gedung perkantoran dengan kategori resiko II dan faktor keutamaan $(\mathrm{Ie})=1,00$.

Pembebanan yang dimasukkan kedalam pemodelan struktur Gedung $\mathrm{X}$ merupakan pembebanan yang bersifat statik dan dinamik (Gambar 4). Pembebanan statik yang diberikan, diantaranya: beban hidup dan beban mati

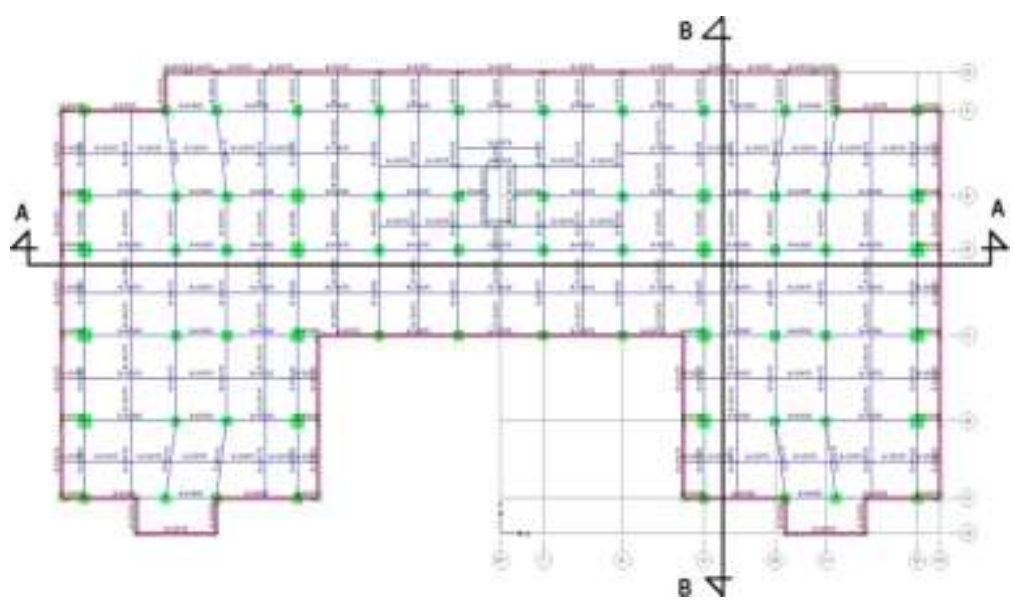

Gambar 4 Denah pemodelan struktur gedung di metode 
berdasarkan PPPURG 1987. Pembebanan dinamik diantaranya terdiri dari beban angin dan beban gempa, namun pada penelitian ini, beban angin pada pemodelan struktur gedung tidak diberikan, karena kecepatan angin di wilayah objek penelitian tidak terlalu berpengaruh atau bernilai kecil.

Tinjauan analisis pembebanan pasal 7.8.2. Nilai Ta juga dapat diperoleh melalui hasil analisis pemodelan ETABS, antara lain: nilai Ta pada mode shape 1 untuk arah-x dan Ta pada mode shape 2 untuk arah-y. Nilai Ta yang diambil harus memenuhi ketentuan syarat bahwa nilai Ta harus lebih besar dari nilai minimum dan tidak perlu melebihi nilai maksimum (Tabel 2).

Tabel 2 Nilai periode getar fundamental

\begin{tabular}{llll}
\hline Arah B-T & Detik & Arah U-S & Detik \\
\hline Ta minimum & 1.94 & Ta minimum & 1.94 \\
Ta maksimum & 2.71 & Ta maksimum & 2.71 \\
Ta mode shape-1 & 2.97 & Ta mode shape-2 & 2.66 \\
diambil nilai Ta & 2.71 & Diambil nilai Ta & 2.66 \\
\hline
\end{tabular}

gempa dalam studi ini menggunakan tinjauan gaya geser dasar seismik respons ragam pertama melalui analisis statik ekivalen lateral $\left(\mathrm{V}_{1}\right)$ dan tinjauan gaya geser dasar seismik melalui analisis spektrum respons ragam $(\mathrm{Vt})$ yang mengacu pada SNI 03-1726-2012.

Gaya geser dasar seismik respons ragam pertama $\left(\mathrm{V}_{1}\right)$ diperoleh dengan cara mengalikan nilai koefisen dasar seismik (Cs) dan jumlah berat seluruh bangunan.
Berdasarkan data Tabel 1, nilai Ta yang diambil harus terletak diantara interval nilai maksimum dan minimum, sehingga nilai periode yang diambil adalah nilai Ta maksimum arah-x sebesar 2,71 s dan nilai Ta maksimum arah-y sebesar 2,71 s. Nilai Ta tersebut dapat digunakan untuk menghitung nilai Cs. Nilai Cs telah dihitung berdasarkan ketentuan SNI 031726-2012 pasal 4.1.2 (Tabel 3).

Tabel 3 Nilai koefisien dasar seismik (Cs)

\begin{tabular}{cccc}
\hline Arah B-T & Detik & Arah U-S & Detik \\
\hline Cs minimum & 0.027 & Cs minimum & 0.027 \\
Cs maksimum & 0.121 & Cs maksimum & 0.121 \\
Cs hitungan & 0.042 & Cs hitungan & 0.041 \\
diambil nilai Cs & 0.042 & diambil nilai Cs & 0.041 \\
\hline
\end{tabular}

Nilai Cs diperoleh berdasarkan ketentuan SNI 03-1726-2012 pasal 4.1.2. Nilai Cs tersebut dipengaruhi oleh periode fundamental struktur $(\mathrm{Ta})$, karena nilai Ta akan digunakan sebagai parameter untuk menghitung nilai Cs. Nilai Ta dihitung dengan batasan nilai minimum dan maksimum berdasarkan SNI 03-1726-2012
Berdasarkan data Tabel 3, nilai Cs yang diambil harus terletak diantara interval nilai maksimum dan minimum, sehingga nilai Cs yang diambil adalahnilai Cs hitungan, yaitu Cs arah-x sebesar 0,042 dan Cs arah-y sebesar 0,041.

Nilai jumlah berat bangunan diperoleh melalui analisis output 
Tabel 4 Rasio partisipasi massa

\begin{tabular}{cccc}
\hline Acc & $\begin{array}{c}\text { Static } \\
\text { percent }\end{array}$ & $\begin{array}{c}\text { Dynamic } \\
\text { percent }\end{array}$ & $\begin{array}{c}\text { Mode } \\
\text { Shape }\end{array}$ \\
\hline $\mathrm{UX}$ & $99,99 \%$ & $89,92 \%$ & 106 \\
$\mathrm{UY}$ & $99,99 \%$ & $90,41 \%$ & 106 \\
\hline
\end{tabular}

pemodelan ETABS sebesar $327.240 \mathrm{kN}$. Data nilai jumlah berat bangunan dan nilai Cs telah diketahui, maka nilai gaya geser dasar respons ragam pertama $\left(\mathrm{V}_{1}\right)$ diperoleh sebagai berikut, $\mathrm{V}_{1}$ arah-x (B-T) sebesar 13.614,54 kN dan $\mathrm{V}_{1}$ arah-y (U-S) sebesar 13.345,93 kN.

Gaya geser dasar seismik spektrum ragam respons $(\mathrm{Vt})$ dapat diperoleh dari hasil analisis program $E T A B S$ melalui data output story shears. Berdasarkan SNI 031726-2012 pasal 11.1.4, nilai story shears (Vt) tersebut harus diberikan nilai besaran skalar. Nilai tersebut merupakan hasil perkalian antara nilai gravitasi bumi dan nilai Ie/R. Nilai R merupakan koefisien modifikasi respons yang diperoleh berdasarkan SNI 03-2847-2012 pasal 7.2.2. Nilai koefisien modifikasi respon (R) yang dipilih sebesar 5 karena sistem rangka struktur penahan gaya seismik yang digunakan Gedung $\mathrm{X}$ termasuk dalam kategori sebagai Sistem Rangka Pemikul Momen Menengah (SRPMM). Nilai Ie merupakan faktor keutamaan yang diperoleh berdasarkan SNI 03-1726-2012 pasal 4.1.2. Nilai faktor keutamaan (Ie) yang digunakan sebesar 1,00 karena Gedung $\mathrm{X}$ termasuk kategori risiko II (perkantoran). Jika nilai Ie dan $\mathrm{R}$ sudah diketahui maka dapat dihitung besaran skalar, sehingga diperoleh U1 untuk arah- $x$ dan U2 untuk arah-y, keduanya bernilai sama yaitu $1,962 \mathrm{~m} / \mathrm{s}^{2}$.

Hasil analisis struktur dapat digunakan jika jumlah tingkat yang akan dianalisis sudah memenuhi kontrol rasio partisipasi massa sebesar 90\%. Hasil analisis jumlah ragam pada beban statik

Tabel 5 Evaluasi nilai 35\% Vt pada setiap lantai untuk nilai $\rho=1$

\begin{tabular}{cccccccc}
\hline Lantal & $\begin{array}{c}\text { Ketinggian } \\
(\mathrm{m})\end{array}$ & $\begin{array}{c}35 \% \mathrm{Vt}-\mathrm{y} \\
(\mathrm{kN})\end{array}$ & $\begin{array}{c}\mathrm{V}-\mathrm{y}(\mathrm{U}-\mathrm{S}) \\
(\mathrm{kN})\end{array}$ & $\begin{array}{c}\text { Ket. } \\
\text { Atap }\end{array}$ & $\begin{array}{c}35 \% \mathrm{Vt}-\mathrm{x} \\
(\mathrm{kN})\end{array}$ & $\begin{array}{c}\text { V-x }(\mathrm{B}-\mathrm{T}) \\
(\mathrm{kN})\end{array}$ & Ket. \\
\hline Penthouse & 59,40 & $4.277,59$ & 190,51 & $\mathrm{BM}$ & $5.482,91$ & 161,14 & $\mathrm{BM}$ \\
12 & $5.277,59$ & 550,55 & $\mathrm{BM}$ & $5.482,91$ & 474,64 & $\mathrm{BM}$ \\
11 & 50,40 & $4.277,59$ & $4.242,38$ & $\mathrm{BM}$ & $5.482,91$ & $5.369,95$ & $\mathrm{BM}$ \\
10 & 46,40 & $4.277,59$ & $5.542,62$ & $\mathrm{M}$ & $5.482,91$ & $7.050,57$ & $\mathrm{M}$ \\
9 & 42,40 & $4.277,59$ & $6.446,18$ & $\mathrm{M}$ & $5.482,91$ & $8.151,93$ & $\mathrm{M}$ \\
8 & 38,40 & $4.277,59$ & $7.103,45$ & $\mathrm{M}$ & $5.482,91$ & $8.941,29$ & $\mathrm{M}$ \\
7 & 34,40 & $4.277,59$ & $7.652,20$ & $\mathrm{M}$ & $5.482,91$ & $9.625,72$ & $\mathrm{M}$ \\
6 & 30,40 & $4.277,59$ & $8.233,83$ & $\mathrm{M}$ & $5.482,91$ & $10.365,61$ & $\mathrm{M}$ \\
5 & 26,40 & $4.277,59$ & $8.894,07$ & $\mathrm{M}$ & $5.482,91$ & $11.213,34$ & $\mathrm{M}$ \\
4 & 22,40 & $4.277,59$ & $9.824,89$ & $\mathrm{M}$ & $5.482,91$ & $12.498,94$ & $\mathrm{M}$ \\
3 & 17,40 & $4.277,59$ & $10.918,44$ & $\mathrm{M}$ & $5.482,91$ & $14.313,95$ & $\mathrm{M}$ \\
2 & 11,40 & $4.277,59$ & $11.418,86$ & $\mathrm{M}$ & $5.482,91$ & $15.086,30$ & $\mathrm{M}$ \\
1 & 6,40 & $4.277,59$ & $11.746,73$ & $\mathrm{M}$ & $5.482,91$ & $15.328,24$ & $\mathrm{M}$ \\
Base-1 & 3,20 & $4.277,59$ & $12.218,31$ & $\mathrm{M}$ & $5.482,91$ & $15.662,62$ & $\mathrm{M}$ \\
Base-2 & 0,00 & $4.277,59$ & $12.221,68$ & $\mathrm{M}$ & $5.482,91$ & $15.665,47$ & $\mathrm{M}$ \\
\hline
\end{tabular}

Ket $=$ Keterangan, $\mathrm{BM}=$ Belum Memenuhi, $\mathrm{M}=$ Memenuhi 


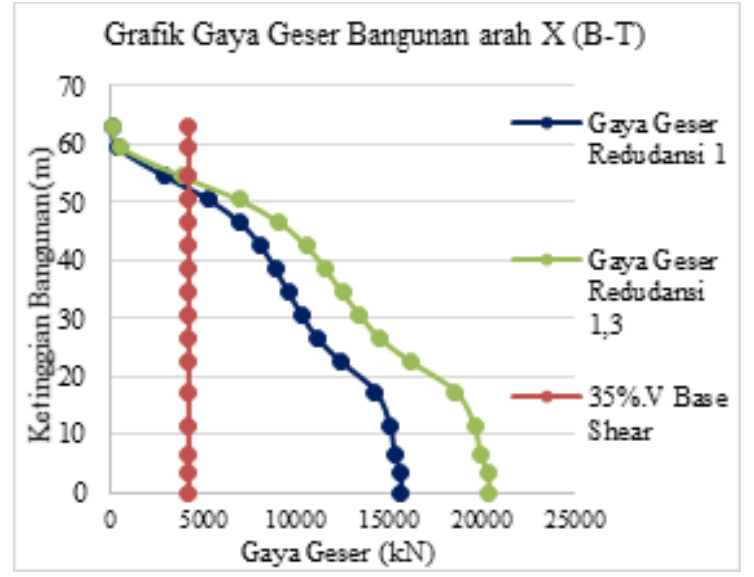

(a)

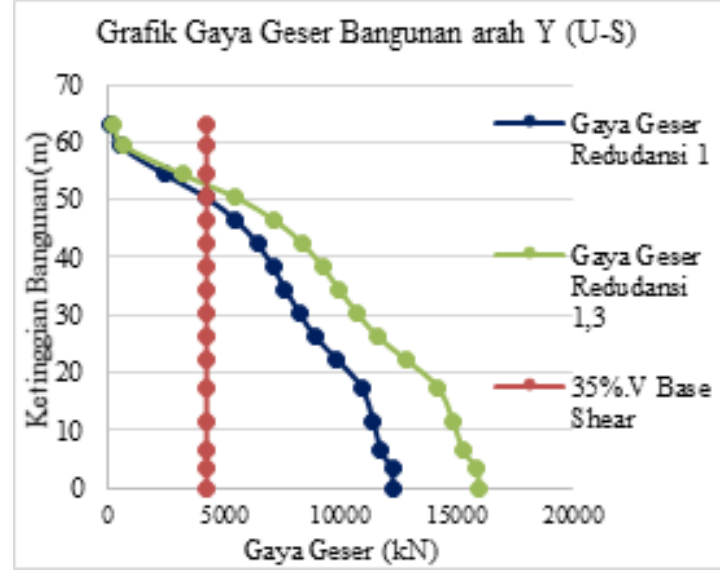

(b)

Gambar 5 Grafik gaya geser bangunan pada (a) arah-x dan (b) arah-y

dan dinamik yang dikeluarkan program ETABS pada modal load participation ratios menunjukkan bahwa nilai partisipasi massa arah percepatan UX dan UY sudah mencapai $90 \%$ pada mode shape ke 106 (Tabel 4).

Persyaratan Gaya Geser Dasar Seismik Spektrum Respons Ragam (Vt)
Hasil analisis program ETABS pada story shears diperoleh bahwa nilai Vt arah$\mathrm{x}(\mathrm{B}-\mathrm{T})$ sebesar $15.665,47 \mathrm{kN}$ dan nilai $\mathrm{Vt}$ arah-y (U-S) sebesar 12.221,68 kN (Tabel 5). Dari analisis gaya geser seismik melalui analisis statik ekivalen lateral sebelumnya telah diperoleh bahwa nilai $\mathrm{V}_{1}$ arah-x (B$\mathrm{T})$ sebesar $13.614,54 \mathrm{kN}$ dan $\mathrm{V}_{1}$ arah-y (US) sebesar 13.345,93 kN. Hasil dari analisis nilai $\mathrm{V}_{1}$ dan nilai $\mathrm{Vt}$ tersebut, diketahui

Tabel 6 Gaya geser lantai (V) terkoreksi untuk $\rho=1,3$

\begin{tabular}{ccccc}
\hline r n.m: & $\begin{array}{c}\text { Tinggi } \\
(\mathrm{m})\end{array}$ & $\begin{array}{c}\text { Ketinggian } \\
(\mathrm{m})\end{array}$ & $\begin{array}{c}\text { V-y }(\mathrm{U}-\mathrm{S}) \\
(\mathrm{kN})\end{array}$ & $\begin{array}{c}\mathrm{V}-\mathrm{x}(\mathrm{B}-\mathrm{T}) \\
(\mathrm{kN})\end{array}$ \\
\hline Atap & 0,00 & 62,90 & 247,66 & 209,48 \\
Penthouse & 3,50 & 59,40 & 715,72 & 617,03 \\
12 & 5,00 & 54,40 & $3.222,86$ & $3.905,04$ \\
11 & 4,00 & 50,40 & $5.515,09$ & $6.980,94$ \\
10 & 4,00 & 46,40 & $7.205,41$ & $9.165,74$ \\
9 & 4,00 & 42,40 & $8.380,03$ & $10.597,51$ \\
8 & 4,00 & 38,40 & $9.234,49$ & $11.623,68$ \\
7 & 4,00 & 34,40 & $9.947,86$ & $12.513,44$ \\
6 & 4,00 & 30,40 & $10.703,98$ & $13.475,29$ \\
5 & 4,00 & 26,40 & $11.562,29$ & $14.577,34$ \\
4 & 4,00 & 22,40 & $12.772,36$ & $16.248,62$ \\
3 & 5,00 & 17,40 & $14.193,97$ & $18.608,14$ \\
2 & 6,00 & 11,40 & $14.844,52$ & $19.612,19$ \\
1 & 5,00 & 6,40 & $15.270,75$ & $19.926,71$ \\
Base-1 & 3,20 & 3,20 & $15.883,80$ & $20.361,41$ \\
Base-2 & 3,20 & 0,00 & $15.888,18$ & $20.365,11$ \\
\hline
\end{tabular}


Tabel 7 Perhitungan story drift dari kinerja batas ultimum arah-x (B-T)

\begin{tabular}{ccccccc}
\hline Lantai & $\begin{array}{c}\text { Tinggi } \\
\text { Lantai } \\
(\mathrm{mm})\end{array}$ & $\begin{array}{c}\text { Total } \\
\text { Drift } \\
(\mathrm{mm})\end{array}$ & $\begin{array}{c}\text { Perpindahan } \\
\text { lantai } \\
(\mathrm{mm})\end{array}$ & $\begin{array}{c}\text { Story } \\
\text { Drift } \\
(\mathrm{mm})\end{array}$ & $\begin{array}{c}\text { Story Drift } \\
\text { Izin }(\Delta \mathrm{a}) \\
(\mathrm{mm})\end{array}$ & $\begin{array}{c}\text { Kontrol } \\
\text { Story Drift }<\Delta \mathrm{a}\end{array}$ \\
\hline Atap & 0 & 120,56 & 2,56 & 11,53 & 24,5 & Aman \\
Penthouse & 3.500 & 117,99 & 4,16 & 18,74 & 35 & Aman \\
12 & 5.000 & 113,83 & 5,28 & 23,76 & 28 & Aman \\
11 & 4.000 & 108,55 & 8,54 & 38,43 & 28 & Tidak Aman \\
10 & 4.000 & 100,01 & 11,30 & 50,84 & 28 & Tidak Aman \\
9 & 4.000 & 88,71 & 11,97 & 53,88 & 28 & Tidak Aman \\
8 & 4.000 & 76,74 & 13,40 & 60,29 & 28 & Tidak Aman \\
7 & 4.000 & 63,34 & 13,11 & 59,02 & 28 & Tidak Aman \\
6 & 4.000 & 50,23 & 12,07 & 54,32 & 28 & Tidak Aman \\
5 & 4.000 & 38,16 & 7,37 & 33,18 & 28 & Tidak Aman \\
4 & 4.000 & 30,78 & 5,12 & 23,02 & 35 & Aman \\
3 & 5.000 & 25,67 & 15,25 & 68,60 & 42 & Tidak Aman \\
2 & 6.000 & 10,42 & 10,06 & 45,26 & 35 & Tidak Aman \\
1 & 5.000 & 0,36 & 0,27 & 1,21 & 22,4 & Aman \\
Base-2 & 3.200 & 0,10 & 0,10 & 0,43 & 22,4 & Aman \\
Base-1 & 3.200 & 0,00 & 0,00 & 0,00 & 0,00 & Aman \\
\hline
\end{tabular}

bahwa nilai $\mathrm{Vt}$ lebih besar dari $0,85 \mathrm{~V}_{1}$ untuk arah-x dan y. Hal ini menunjukkan bahwa dalam pembebanan gempa untuk $\mathrm{Vt}$ arah-x maupun arah-y tidak perlu dikali $\left(0,85 \mathrm{~V}_{1}\right) / \mathrm{Vt}$ atau faktor skala.

\section{Faktor Redudansi ( $\rho)$ untuk Pembebanan Gempa}

Hasil analisis untuk faktor redudansi pada 35\% Vt arah-x dan y diperoleh bahwa untuk $35 \% \mathrm{Vt}$ untuk arah-x sebesar $5.482,91 \mathrm{kN}$ dan nilai $35 \% \mathrm{Vt}$ untuk arah-y sebesar 4.277,59 kN. Hasil evaluasi $35 \% \mathrm{Vt}$ pada setiap lantai untuk $\rho=1$ disajikan pada Tabel 5.

Tabel 5 menunjukkan bahwa hasil evaluasi nilai gaya geser lantai (V) arah-x dan arah-y pada lantai atap sampai lantai 11, belum memenuhi $35 \%$ dari Vt arah- $\mathrm{x}$ dan arah-y, sehingga nilai Vt arah-x dan arah-y harus dikalikan dengan faktor redudansi $(\rho)$ sebesar 1,3. Pada program $E T A B S$, nilai faktor redudansi $(\rho)=1,3$ dapat diberikan dengan cara mengalikan nilai faktor redudansi tersebut kedalam nilai faktor skala untuk U1 pada arah-x dan U2 pada arah y (Tabel 6).

Hasil analisis pengaruh faktor redudansi 1,3 menunjukkan bahwa nilai gaya geser lantai akibat beban gempa rencana menjadi lebih besar setelah diberikan faktor redudansi tersebut, hal ini dimaksudkan agar desain struktur dapat dievaluasi dengan pembebanan gempa batas ultimum (Gambar 5 (a) dan (b)).

\section{Kinerja Batas Ultimum dari Simpangan Antar Lantai Tingkat (Story Drift)}

Penentuan batas izin simpangan antar lantai tingkat (story drift) dihitung berdasarkan SNI 03-1726-2012 pasal 7.12.1. Gedung $X$ dibangun dengan sistem penahan seismik berupa dinding geser batu bata dan termasuk dalam jenis gedung perkantoran yang memiliki kategori resiko 
Tabel 8 Perhitungan story drift dari kinerja batas ultimum arah-y (U-S)

\begin{tabular}{|c|c|c|c|c|c|c|}
\hline Lanta1 & $\begin{array}{l}\text { Tinggi } \\
\text { Lantai } \\
(\mathrm{mm})\end{array}$ & $\begin{array}{l}\text { Total } \\
\text { Drift } \\
(\mathrm{mm})\end{array}$ & $\begin{array}{c}\text { Perpindahan } \\
\text { lantai } \\
(\mathrm{mm})\end{array}$ & $\begin{array}{l}\text { Story } \\
\text { Drift } \\
(\mathrm{mm})\end{array}$ & $\begin{array}{l}\text { Story Drift } \\
\text { Izin }(\Delta \mathrm{a}) \\
(\mathrm{mm})\end{array}$ & $\begin{array}{c}\text { Kontrol } \\
\text { Story Drift }<\Delta \mathrm{a}\end{array}$ \\
\hline Atap & 0 & 161,40 & 4,84 & 21,77 & 24,5 & Aman \\
\hline Penthouse & 3.500 & 156,56 & 11,32 & 50,92 & 35 & Tidak Aman \\
\hline 12 & 5.000 & 145,24 & 5,29 & 23,81 & 28 & Aman \\
\hline 11 & 4.000 & 139,95 & 8,17 & 36,77 & 28 & Tidak Aman \\
\hline 10 & 4.000 & 131,78 & 10,93 & 49,19 & 28 & Tidak Aman \\
\hline 9 & 4.000 & 120,85 & 12,16 & 54,74 & 28 & Tidak Aman \\
\hline 8 & 4.000 & 108,69 & 13,90 & 62,56 & 28 & Tidak Aman \\
\hline 7 & 4.000 & 94,78 & 14,49 & 65,20 & 28 & Tidak Aman \\
\hline 6 & 4.000 & 80,30 & 15,11 & 68,00 & 28 & Tidak Aman \\
\hline 5 & 4.000 & 65,18 & 14,02 & 63,10 & 28 & Tidak Aman \\
\hline 4 & 4.000 & 51,16 & 17,40 & 78,28 & 35 & Tidak Aman \\
\hline 3 & 5.000 & 33,77 & 22,49 & 101,20 & 42 & Tidak Aman \\
\hline 2 & 6.000 & 11,28 & 10,82 & 48,69 & 35 & Tidak Aman \\
\hline 1 & 5.000 & 0,46 & 0,35 & 1,57 & 22,4 & Aman \\
\hline Base-2 & 3.200 & 0,11 & 0,11 & 0,48 & 22,4 & Aman \\
\hline Base-1 & 3.200 & 0,00 & 0,00 & 0,00 & 0,00 & Aman \\
\hline
\end{tabular}

II, sehingga nilai batas simpangan antar tingkat yang diizinkan pada Gedung $\mathrm{X}$ bernilai 0,007 hsx. Nilai hsx merupakan tinggi lantai tingkat dibawahnya. Hasil perhitungan nilai story drift yang diperoleh berdasarkan SNI 03-1726-2012 pasal 7.9.3. ditunjukkkan pada Tabel 7 dan Tabel 8.

Tabel 7 menunjukkan nilai story drift maksimum yang diperoleh dari kinerja batas ultimum untuk arah-x sebesar 68,60 $\mathrm{mm}$. Nilai simpangan antar lantai (story drift) pada arah-x untuk lantai 2, 3, 5, 6, 7, 8, 9, 10 dan 11 dinyatakan tidak aman, karena nilai story drift pada lantai tersebut lebih besar dari nilai story drift izin.

Tabel 8 menunjukkan nilai story drift maksimum yang diperoleh dari kinerja batas ultimum untuk arah-y sebesar 101,20 $\mathrm{mm}$. Nilai simpangan antar lantai (story drift) pada arah-y untuk lantai 2, 3, 4, 5, 6, $7,8,9,10,11$ dan lantai penthouse dinyatakan tidak aman, karena nilai strory drift pada lantai tersebut lebih besar dari nilai story drift izin.

Hasil analisis pembebanan gempa dinamik spektrum respons ragam menyatakan bahwa Gedung $X$ yang berlokasi di Jakarta tersebut, belum memenuhi syarat (aman) terhadap kinerja batas ultimum yang dihitung berdasarkan SNI 03-1726-2012.

\section{KESIMPULAN}

\section{Simpulan}

Berdasarkan hasil analisis pembebanan gempa dinamik spektrum respons ragam pada arah- $\mathrm{x}$ dan $\mathrm{y}$ diperoleh bahwa nilai gaya geser dasar spektrum respons ragam $(\mathrm{Vt})$ lebih besar dari 85 persen gaya geser dasar respons ragam pertama melalui prosedur statik ekivalen lateral $\left(\mathrm{V}_{1}\right)$. Dari hasil tersebut dapat disimpulkan bahwa nilai akhir respons dinamik struktur gedung terhadap 
pembebanan gempa nominal akibat pengaruh gempa rencana telah memenuhi persyaratan SNI 03-1726-2012. Hasil analisis pembebanan gempa dinamik respon spektrum pada Gedung $X$ menunjukkan bahwa nilai story drift maximum atau simpangan maksimum kinerja batas ultimum arah-x sebesar 68,60 $\mathrm{mm}$ dan arah-y sebesar 101,20 mm.

Hasil analisis pembebanan gempa dinamik spektrum respons ragam menyatakan bahwa Gedung $\mathrm{X}$ yang berlokasi di Jakarta tersebut, belum memenuhi syarat (aman) terhadap kinerja batas ultimum atau simpangan antar lantai tingkat yang diizinkan $(\Delta \mathrm{a})$ yaitu $0,007 \mathrm{hsx}$.

\section{Saran}

1) Perlunya analisa untuk mengetahui elemen struktur yang dianggap lemah dan rekomendasi perkuatan strukturnya sehingga dapat mencegah terjadinya kegagalan struktur gedung.

2) Pemilik gedung bertingkat tinggi yang memiliki jumlah lantai lebih dari 10 khususnya di wilayah Jakarta, diharapkan dapat melakukan audit evaluasi internal guna mendapatkan sertifikasi kelaikan fungsi bangunan dari Dinas Penataan Kota atau Dinas tersosialisasi Peraturan Menteri Pekerjaan Umum Nomor 25/PRT/M/2007.

\section{DAFTAR PUSTAKA}

Afriadi Y, Satyarno I. 2013. Perbandingan spektra desain beberapa kota besar di Indonesia dalam SNI 2012 Gempa dan SNI 2002 [Internet]. Konferensi Nasional Teknik Sipil 7, 24-26 Oktober 2013. Surakarta (ID) Universitas Sebelas Maret. hlm 299305; [diunduh 2015 Juni 20]. Tersedia pada http://sipil.ft.uns.ac.id/konteks7/prosi ding/233S.pdf
Asrurifak M, Irsyam M, Hutapea, BM, Ridwan M, Pramatatya AV, Dharmawansyah D. 2013. Pengembangan Peta Klasifikasi Tanah dan Kedalaman Batuan Dasar untuk Menunjang Pembuatan Peta Mikrozonasi Jakarta Dengan Menggunakan Mikrotremor Array. [Internet] 17th Annual Scientific Meeting 2013 November 13-14, Jakarta (ID). hlm. 67-72; [diunduh 2015 Agustus 23]. Tersedia pada: https://www.academia.edu/6296595 /Pengembangan_Peta_Klasifikasi_ Tanah_dan_Kedalaman_Batuan_Da sar_untuk_Menunjang_Pembuatan_ Peta_Mikrozonasi_Jakarta_Dengan _Menggunakan_Mikrotremor_Arra $\mathrm{y}$

Badan Standardisasi Nasional (BSN). 2013. SNI 03-2847-2013 Persyaratan Beton Struktural untuk Bangunan Gedung. Jakarta (ID): BSN.

Badan Standardisasi Nasional (BSN). 2012. SNI 03-1726-2012 Tata Cara Perencanaan Ketahanan Gempa Untuk Bangunan Gedung. Jakarta (ID): BSN.

Budiono B, Supriatna L. 2011. Studi Komparasi Desain Bangunan Tahan Gempa dengan Menggunakan SNI 03-1726-2002 dan RSNI 03-1726201X. Bandung (ID): ITB Pr.

Christiawan I, Triwiyono A, Christady H. 2008. Evaluasi kinerja dan perkuatan struktur gedung guna alih fungsi bangunan. Studi kasus: perubahan fungsi ruang kelas menjadi ruang perpustakaan pada lantai II gedung G Universitas Semarang. Forum Teknik Sipil. 18(1): 725-738.

Departemen Pekerjaan Umum (DPU). 1987. Pedoman Perencanaan Pembebanan untuk Rumah dan Gedung. Jakarta (ID): DPU.

Departemen Pekerjaan Umum (DPU). 2007. Peraturan Menteri Pekerjaan 
Umum Nomor 25/PRT/M/2007

tentang Pedoman Setifikat Laik

Fungsi Bangunan. Jakarta (ID).

Direktorat Jendral Cipta Karya.

Priyono A, Budi AS, Supardi. 2014. Evaluasi

Kinerja Struktur Gedung 10 Lantai dengan Analisis Respons Spektrum ditinjau pada Drift dan Displacement menggunakan Software ETABS. eJurnal Matriks Teknik Sipil [Internet]. [diunduh 2015 Mei 19]; 2(3): 534-541.

Tersedia

pada:http://matriks.sipil.ft.uns.ac.id/ind ex.php/MaTekSi/article/viewFile/249/ 242

Snell LM. 2012. Using the Rebound Hammer [Internet]. Proceedings Of The 11th Annual Mongolian Concrete Conference, June 2012. hlm tidak disebutkan; [diunduh 2015 Juni 21]. Tersedia pada http://wtus.com/pdf/snell_Hammer.pdf

Yalciner H, Sensoy S, Eren O. 2015. Seismic Performance Assessment of a Corroded 50-Year-Old Reinforced Concrete Building. Journal of Structural Engineering. 144(2):1-11. doi: 10.1061/(ASCE)ST.1943-

541X.000126 
